\title{
Penerapan Algoritma Djikstra Pada Sistem Monitoring Petugas Lapangan Pemkab Bekasi Berbasis Android
}

\author{
April Lia Hananto ${ }^{1}$, Bayu Priyatna ${ }^{2}$, Aviv Yuniar Rahman ${ }^{3}$ \\ 12aprilia@ubpkarawang.ac.id, ${ }^{2}$ bayu.priyatna@ubpkarawang.ac.id, ${ }^{3}$ aviv@widyagama.ac.id \\ ${ }^{1,2}$ Program Studi Sistem Informasi, Universitas Buana Perjuangan Karawang, \\ ${ }^{3}$ Program Studi Teknik Informatika, Universitas Widyagama Malang
}

\begin{abstract}
Google is a multi-national company in the United States engaged in Internet services and products. These products include search technology, web computing, software, and advertising; most of the profits come from AdWords. "Android is one of the operating systems that now dominate the market as a platform used for installing software / mobile applications by developers, Bekasi regency government has a KOMINFO division that regulates the entire system that is spread throughout the district of Bekasi. Problems faced by KOMINFO Bekasi are; The location points of the distribution of consumers are not mapped so that the division of territory is difficult to determine, the visit of field officers is not timely and so forth. The method in this study uses Djikstra. The results of testing using alpha testing from field staff data showed that $79.62 \%$ stated strongly agree, $9.26 \%$ approved, and the rest said disagreed. Most of the officers agree with the system that has been made, and only a few officers who do not agree with the application. From the admin and financial officer data shows that $90.44 \%$ stated strongly agree, $1.55 \%$ approved, and the rest said disagree. It can be concluded that the monitoring system that has been made is easy and feasible to use.
\end{abstract}

Intisari-Google adalah sebuah perusahaan multi nasional Amerika Serikat yang bergerak pada jasa dan produk Internet, produk-produk tersebut meliputi teknologi pencarian, komputasi web, perangkat lunak, dan periklanan, sebagian besar labanya berasal dari AdWords. Android merupakan salah satu sistem operasi yang sekarang mendominasi pasar sebagai platform yang digunakan untuk pemasangan software/aplikasi mobile oleh para developer, Pemda kabupaten Bekasih memiliki divisi KOMINFO yang mengatur seluruh sistem yang tersebar di seluruh wilayah kabupaten Bekasi, namun saat ini prmasalahan yang dihadapi KOMINFO Bekasi adalah; Titik-titik lokasi penyebaran konsumen tidak di petakan sehingga pembagian wilayah sulit untuk ditetapkan, Kunjungan petugas lapangan tidak tepat waktu dan lain sebagainya. Metode dalam penelitian ini menggunakan Djikstra. Hasil pengujian menggunakan alpha testing dari data petugas lapangan menunjukan bahwa 79,62\% menyatakan sangat setuju, 9,26\% menyatakan setuju dan sisanya menyatakan tidak setuju. Sebagian banyak petugas setuju dengan sistem yang telah dibuat dan hanya sedikit petugas yang tidak setuju dengan aplikasi tersebut. Dari data admin petugas dan keuangan menunjukan bahwa 90,44\% menyatakan sangat setuju, $1,55 \%$ menyatakan setuju dan sisanya menyatakan tidak setuju. Dapat disimpulkan bahwa sistem monitoring yang telah dibuat mudah dan layak untuk digunakan.

Kata Kunci-Google; KOMINFO; Monitoring; Djigstra; Alpha Testin

\section{PENDAhuluan}

Google adalah sebuah perusahaan multinasional Amerika Serikat yang bergerak pada jasa dan produk Internet. Produkproduk tersebut meliputi teknologi pencarian, komputasi web, perangkat lunak, dan periklanan, sebagian besar labanya berasal dari AdWords."Banyak sekali pemanfaatan produkproduk google oleh masyarakat sebagai media sumber pengetahuan maupun media untuk berbisnis salahsatunya adalah Google Map, kini google map sangatlah membantu para pengembang aplikasi yang memang membutuhkan fasilitas untuk sumber informasi tempat/lokasi, contohnya yang berkembang di negara Indonesia seperti: Gojek, Grab, Traveloka dan masih banyak yang lainnya [1].

Android merupakan salah satu sistem operasi yang sekarang mendominasi pasar sebagai platform yang digunakan untuk pemasangan software/aplikasi mobile oleh para developer, mulai dari games, e-learning, ebook, ecommerce dan lain sebagainya baik free maupun berbayar [2]. Penggunaan prangkat android saat ini menjadi kebutuhan yang harus dipenuhi untuk menunjang kegiatan baik formal maupun non formal, baik sebatas kepuasan pribadi maupun ketentuan yang harus dijalani. Hampir seluruh fasilitas dari google diterapkan juga pada android device kususnya aplikasi-aplikasi penunjang kebutuhan dalam bekerja seperti: Google Office, Google Drive, Gmail, Google Class Room, Google Map dan masih banyak yang lainnya.

Istilah monitoring atau pemantauan merupakan kegiatan untuk melihat atau mengamati suatu proses pelaksanaan kegiatan yang sedang/belum dilakukan. Melalui monitoring dapat melihat aktivitas atau kegiatan yang dilakukan oleh user/program apakah berjalan sesuai atau kurang sesuai dengan yang di harapan [3].

Pemerintah Kabupaten (PEMKAB) Bekasi Provinsi Jawabarat memiliki fasilitas jaringan yang dihubungkan keberbagai lokasi mulai dari kantor dinas hingga sekolahsekolah yang terletak di wilayah pemerintah kabupaten Bekasi, sehingga menjadi kompeksitas tersendiri didalam melakukan perawatan terhadap perangkat-perangkat jaringan di lokasi-lokasi tersebut. Maka dari itu pemerintah kabupaten bekasi membentuk tim khusus yang dibuat oleh KOMINFO 
(Kementerian Komunikasi dan Informatika Republik Indonesia) Kabupaten Bekasi untuk melakukan monitoring perangkat jaringan internet. Secara teknis monitoring yang dilakukan adalah kunjungan secara personal ke lokasi/tempattempat ketika terjadi permasalahan internet yang tujuannya adalah tim dapat mengatasi permasalahan di lokasi tersebut.

Berdasarkan hasil dari wawancara kepada ketua KOMINFO Bekasi dan Staff IT. Bahwa kegiatan monitoring belum efektif, dikarenakan: 1. Titik-titik lokasi penyebaran konsumen tidak di petakan sehingga pembagian wilayah sulit untuk ditetapkan, 2. Kunjungan petugas lapangan tidak tepat waktu, mengakibatkan permasalahan pada jaringan tidak cepat untuk tangani, 2. Manipulasi data Kunjungan oleh petugas lapangan. 3. Mengerjakan pekerjaan dengan waktu yang lama sedangkan permasalahan tidak begitu sulit sehingga oknum petugas meminta bayaran lebih.

Berdasarkan permasalahan tersebut maka perlu dibuatkan suatu sistem yang dapat memonitoring pekerjaan tim/petugas lapangan Pemkab Bekasi, sehingga setiap kegiatan monitoring menjadi terpantau dan lebih efektif.

\section{METODE PENELITIAN}

\section{A. Google Map Pada Perangkat Android}

Perangkat seluler merupakan alat yang digunakan oleh pengguna untuk mengakses layanan LBS (Location based service), untuk mengirim permintaan dan mengambil hasil. Perangkat tersebut dapat berupa perangkat navigasi portabel (PND), Asisten Data Pribadi (PDA), laptop, ponsel, dan sebagainya. Aplikasi adalah antarmuka bagi pengguna untuk mengakses layanan LBS. Perangkat lunak yang dikembangkan oleh penyedia aplikasi, diunduh dan diinstal pada ponsel pengguna alat. Aplikasi spesifik biasanya dikembangkan untuk layanan LBS tertentu. Karena pembatasan perangkat seluler (ukuran layar kecil, daya prosesor dan memori terbatas, kapasitas baterai), LBS aplikasi harus ringan dan hemat baterai [1].

Android menyediakan beberapa objek untuk penanganan peta dalam sistem LBS seperti Map View yang ditampilkan peta. Untuk menggunakan kelas Map Activity tersebut. Untuk menampilkan informasi keterangan peta, disini menyediakan kelas overlay. Bahkan menyediakan layout yang dengan sendirinya seseorang dapat dengan mudah membuat dan menampilkan beberapa layer pada peta. Selain itu, ada ketentuan yang cukup untuk memperbesar peta, melokalkan peta dengan cara Map Controller [2]

\section{A. Monitoring}

Monitoring merupakan suatu proses analisis informasi yang berlandaskan penanda ditetapkan dengan cara yang teratur yberkaitan dengan pelaksanaan kegiatan sehingga dilakukan tindakan pengecekan untuk kesempurnaan kegiatan senajutnya. Kesamarataan dapat paparkan sebagai (Awareness) mengenai apasaja yang diketahui [3].

Istilah monitoring atau pemantauan merupakan kegiatan untuk melihat atau mengamati suatu proses pelaksanaan kegiatan yang sedang/belum dilakukan. Melalui monitoring dapat melihat aktivitas atau kegiatan yang dilakukan oleh user/program apakah berjalan sesuai atau kurang sesuai dengan yang di harapan [4].
Monitoring system dapat mendeteksi setiap masalah ataupun gangguan pada sistem, sistem mempunyai log disetiap terjadinya ganguan secara detail. Sehingga mempermudah administrator untuk dapat menganalisa penyebab terjadinya gangguan secara cepat [5]. Temuan hasil pemantauan adalah informasi untuk proses evaluasi sehingga hasilnya adalah apakah program yang ditetapkan dan dilaksanakan mendapatkan hasil atau tidak [6]. Nilai proses monitoring adalah untuk mendapatkan informasi keadan atau situasi, yang padadasarnya informasi yang penting akan selalu menghasilkan validasi yang bernilai tinggi sesuai dengan prinsip dari informasi sendiri yaitu dapat dipercaya keasliannya dan jelas keberadaan sumbernya [7].

\section{B. Clent-Server}

Merupakan suatu komponen yang terdiri atas aplikasi database dan server DBMS. Setiap kegiatan yang lakukan oleh pemakai akan jauh lebih dulu dilakukan oleh client. Selanjutnya melakukan tindakan agar proses yang berjalan sebisa mungkin dikerjakan sendiri. Jika terdapat proses yang melibatkan data yang tersimpan pada database barulah client menangani interaksi dengan server [8].

Penunjang kebutuhan interaksi antara client dengan server salah satunya adalah internet. Hadirnya internet memberikan alternatif bagi pengguna dalam memanfaatkan pencarian informasi yang dibutuhkan [9]. Layanan server dijalankan pada mesin-mesin server virtual di dalam mesin server fisik [10].

\section{Model Rpid Aplication Development (RAD)}

Metode Rapid Application Development (RAD) sebagaimana dinyatakan oleh James Martin erdiri dari empat fase: fase perencanaan persyaratan, fase desain pengguna, fase konstruksi, dan fase cutover. Setiap fase akan dilaksanakan secara berurutan untuk mengembangkan CLIS, dimulai dari tahap perencanaan persyaratan dan berakhir dengan fase cutover [11]. Pada Gambar 1 merupakan siklus dari RAD:

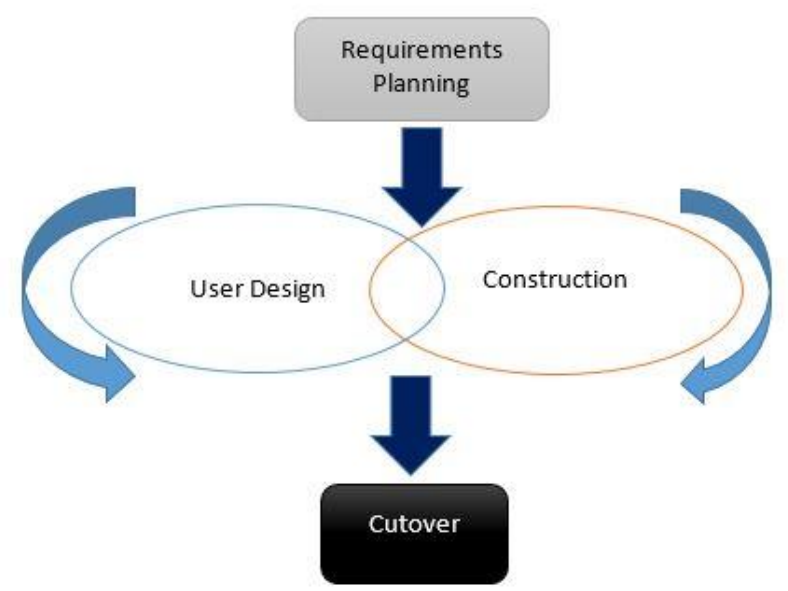

Gambar 1. Metode rapid application development (RAD) [12]

Empat fase utama RAD dapat dibagi menjadi beberapa fase yang lebih spesifik seperti yang digambarkan dalam Gambar 1. Tujuan umum dari pemecahan fase adalah untuk memberikan informasi langkah demi langkah bagi pengembang yang akan mencoba menggunakan model RAD untuk membangun perangkat lunak. Seperti yang terlihat pada gambar, ada 2 loop jika-kondisional, setiap loop menunjukkan 
seberapa kuat keterlibatan pengguna dalam model. Misalnya, loop pertama ditampilkan bahwa tahap perencanaan persyaratan tidak akan maju ke fase berikutnya ketika informasi tentang persyaratan sistem tidak lengkap dan kelengkapan informasi diputuskan oleh pengguna. Rincian tentang setiap fase utama RAD dan hasil pada setiap fase akan dijelaskan pada bagian selanjutnya [12].

\section{Algoritma Djigstra}

Shortest path adalah pencarian rute terpendek antara titik yang ada pada graf $G$. masalah lintasan terpendek adalah bagaimana kita mencari sebuah jalur pada graf yang meminimumkan jumlah bobot edge pembentuk jalur tersebut. Algoritma Dijkstra adalah salah satu metode untuk memecahkan masalah pencarian rute terpendek [13]. Dalam program Dijkstra biasanya berfungsi untuk mencari jarak terpendek antara satu kota dengan kota yang lain, caranya dengan terlebih dahulu mengetahui kota awal dan kota akhir yang tersimpan dalam variabel [14].

Algoritma yang ditemukan oleh Dijkstra untuk mencari path terpendek merupakan algoritme yang lebih efisien dibandingkan algoritme Warshall, meskipun implementasinya juga lebih sukar. Misalkan $G$ adalah graf berarah berlabel dengan titik-titik $\mathrm{V}(\mathrm{G})=\{\mathrm{V} 1, \mathrm{~V} 2, \ldots \mathrm{Vn}\}$ dan path terpendek yang dicari adalah dari v1 ke vn. Algoritme dijkstra dimulai dari titik v1. Dalam iterasinya, algoritme akan mencari satu titik yang jumlah bobotnya dari titik 1 terkecil. Titik-titik yang terpilih dipisahkan dan titik-titik tersebut tidak diperhatikan lagi dalam iterasi berikutnya [15]. Pada Gambar 2 merupakan graph dalam algoritma Dijkstra:

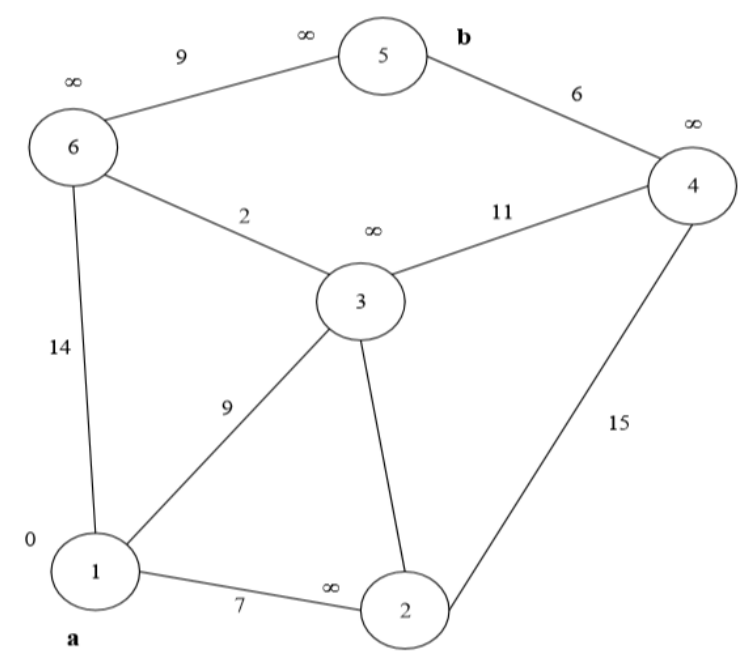

Gambar 2. Contoh graph pada algoritme dijkstra [15].

Pertama-tama tentukan titik mana yang akan menjadi node awal, kemudian beri bobot jarak pada node pertama ke node terdekat satu persatu, algoritme dijkstra akan melakukan pengembangan pencarian dari satu titik ke titik lain dan ke titik selanjutnya tahap demi tahap. Urutan logika dari algoritme dijkstra sebagai berikut:

1. Beri nilai bobot (jarak) untuk setiap titik ke titik lainnya, lalu set nilai 0 pada node awal dan tak hingga terhadap node lain (belum terisi).
2. Set semua node belum terjamah dan set node awal sebagai node keberangkatan.

3. Dari node keberangkatan, pertimbangkan node tetangga yang belum terjamah dan hitung jaraknya dari titik keberangkatan. Sebagai contoh, jika titik keberangkatan A ke B memiliki bobot jarak 6 dan dari B ke node $\mathrm{C}$ berjarak 2 , maka jarak ke $\mathrm{C}$ melewati $\mathrm{B}$ menjadi $6+2=8$. Jika jarak ini lebih kecil dari jarak sebelumnya (yang telah terekan sebelumnya) hapus data lama, simpan ulang data jarak dengan jarak yang baru.

4. Saat kita selesai mempertimbangkan setiap jarak terhadap node tetangga, tandai node yang telah terjamah sebagai node terjamah. Node terjamah tidak akan pernah di cek kembali, jarak yang disimpan adalah jarak terakhir dan yang paling minimal bobotnya.

5. Set node belum terjamah dengan jarak terkecil (dari node keberangkatan) sebagai node keberangkatan selanjutnya dan lanjutkan dengan kembali ke step 3 [15].

\section{E. Model Pengembangan Sistem}

Penelitian ini menggunakan model pengembangan sistem RAD (Model Rpid Aplication Development), berikut pada Gambar 3 merupagan flowgraf metodologi dan pengembangan sistem pada penelitian ini:

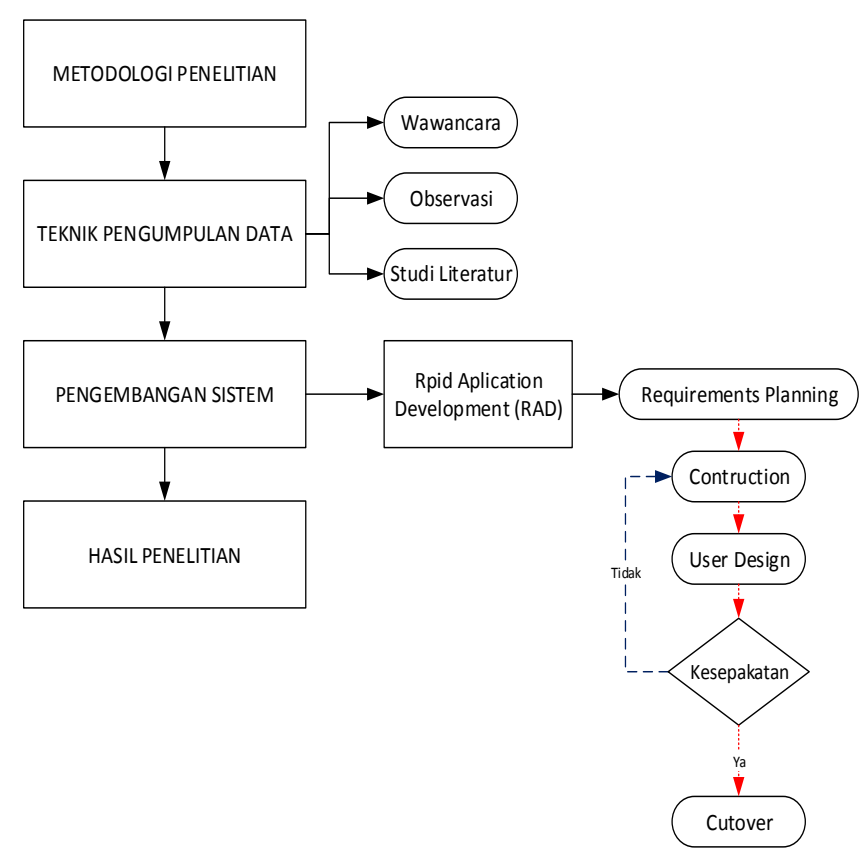

Gambar 3. Metodologi dan model pengembangan sistem

1. Teknik Pengumpulan Data

Dalam megumpulkan data peneliti menggunakan beberapa metode antara lain:

a. Metode observasi.

Metode ini digunakan untuk mendapatkan informasi dengan mengadakan pengamatan dan pencatatan secara teliti tentang sistem monitoring yang sedang berjalan.

b. Metode Wawancara

Metode pengumpulan data melalui pengamatan dengan melakukan tanya jawab yang dilakukan secara lisan kepada pemrintah kabupaten Bekasi. 
c. Studi Literatur

mengenai hal-hal atau variabel-variabel yang berupa jurnal ilmiah, buku, modul workshop, catatan, transkrip, buku, surat kabar, majalah, notulen, rapat, agenda dan sebagainya.

2. Analisa Data dan Testing

Analisis data pada penelitian ini menggunakan teknik deskriptif kuantitatif yang menggambarkan sistem monitoring

\section{HASIL DAN PEMBAHASAN}

Dari analisis kebutuhan sistem berdasarkan wawancara, observasi, studi literatur dan juga hasil dari kesepakatan stakeholder dihasilkan suatu rancangan sistem yang dibuat kedalam bentuk use case, activity dan class diagram:

\section{A. Perancangan Sistem Baru}

1. Use Case Diagram Sistem Monitoring

Pada rancangan sistem baru ini dibuat atau dituangkan kedalam use case diagram untuk mengetahui aktor-aktor yang terlibat dengan sistem, Gambar 4 adalah use case diagram monitoring:

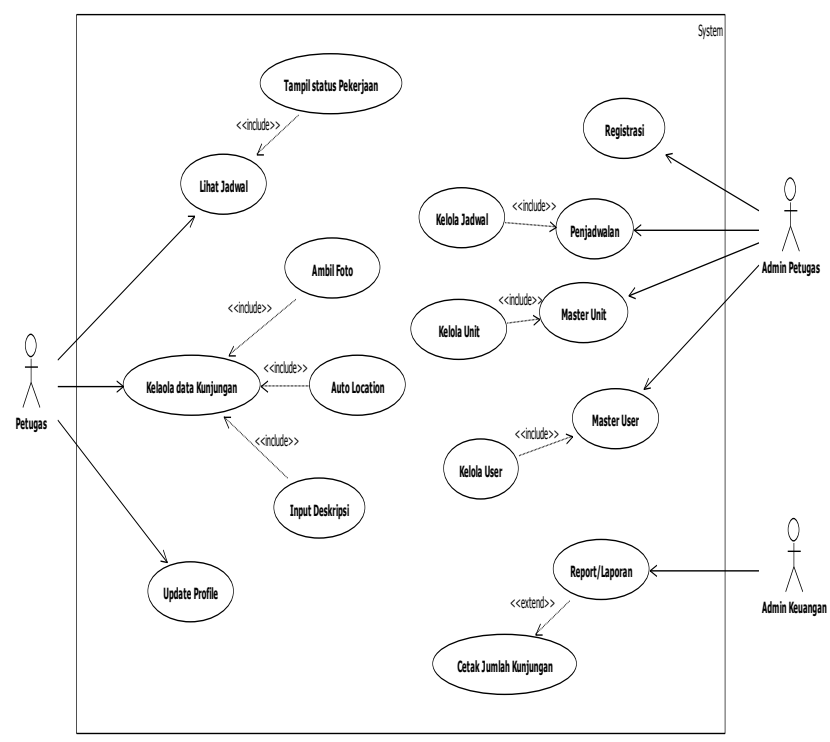

Gambar 4. Use case diagram monitoring

Pada gambar 4 menggambarkan terdapat 3 aktor yaitu; petugas, dimana petugas ini dapat mengakses kelola data profil, melihat jadwal dan mengelola data kunjungan, berikutnya Admnin petugas dapat mengakses, master unit, penjadwalan, registrasi dan master user termasuk mengatur lokasi atau area-area yang menjadi tanggungjawab petugas dengan melakukan pemetaan, dan yang terakhir Admin keuangan mencetak hasil dari laporan kunjungan petugas.

\section{B. Activity Diagram}

Pada activity diagram ini menggambarkan interaksi aktor denga sistem seperti yang digambarkan pada Use case diagram sistem monitoring. Gambar 5, Gambar 6, Gambar 7, Gambar 8 dan Gambar 9 menggambarkan masing-masing aktifitas pada sistem monitoring:

\section{Activity Diagram Petugas}

Petugas yang dimaksud pada aktivity diagram disini adalah petugas lapangan yang mana sebagai ujung tombak pelaksanaan monitoring. Berikut pada gambar 5 adalah Activity diagram Petugas:

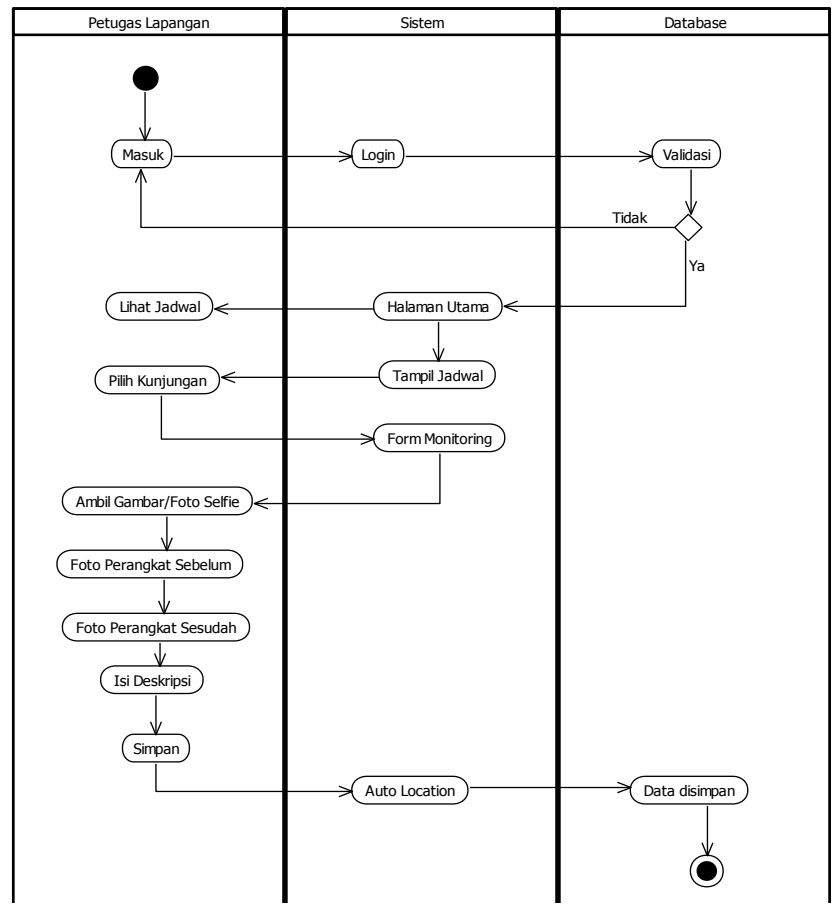

Gambar 5. Activity diagram petugas lapangan

2. Activity Diagram Admin Petugas

Admin Petugas yang dimaksud pada aktivity diagram disini adalah administrator yang mengatur petugas lapangan yang mana sebagai manajemen pelaksanaan monitoring. Berikut pada Gambar 6 adalah Activity diagram Admin Petugas:

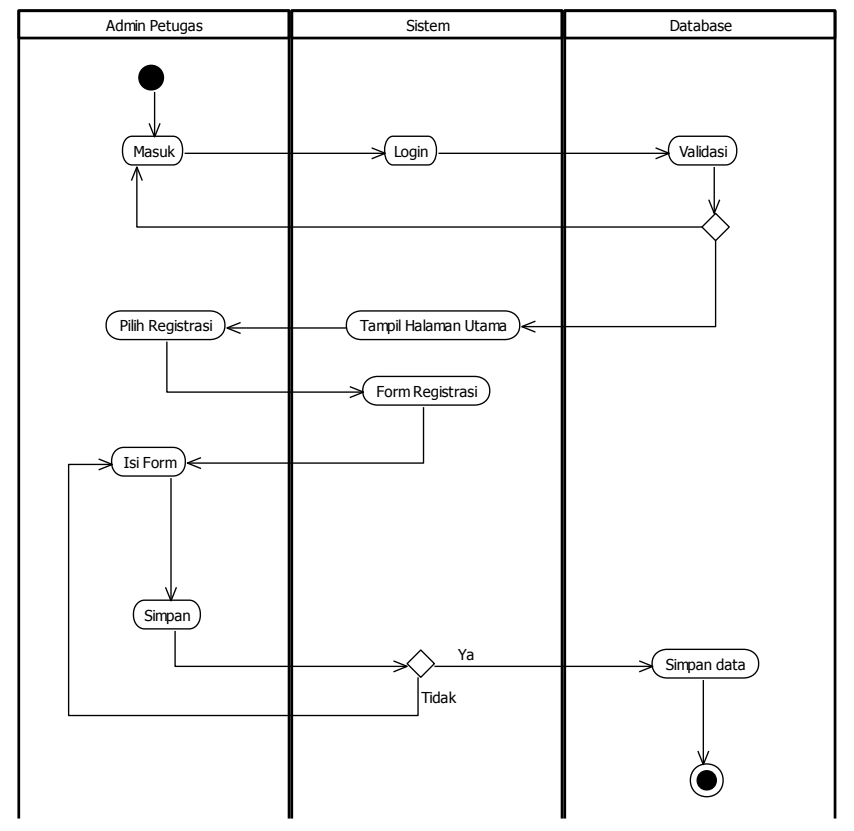

Gambar 6. Activity diagram registrasi 


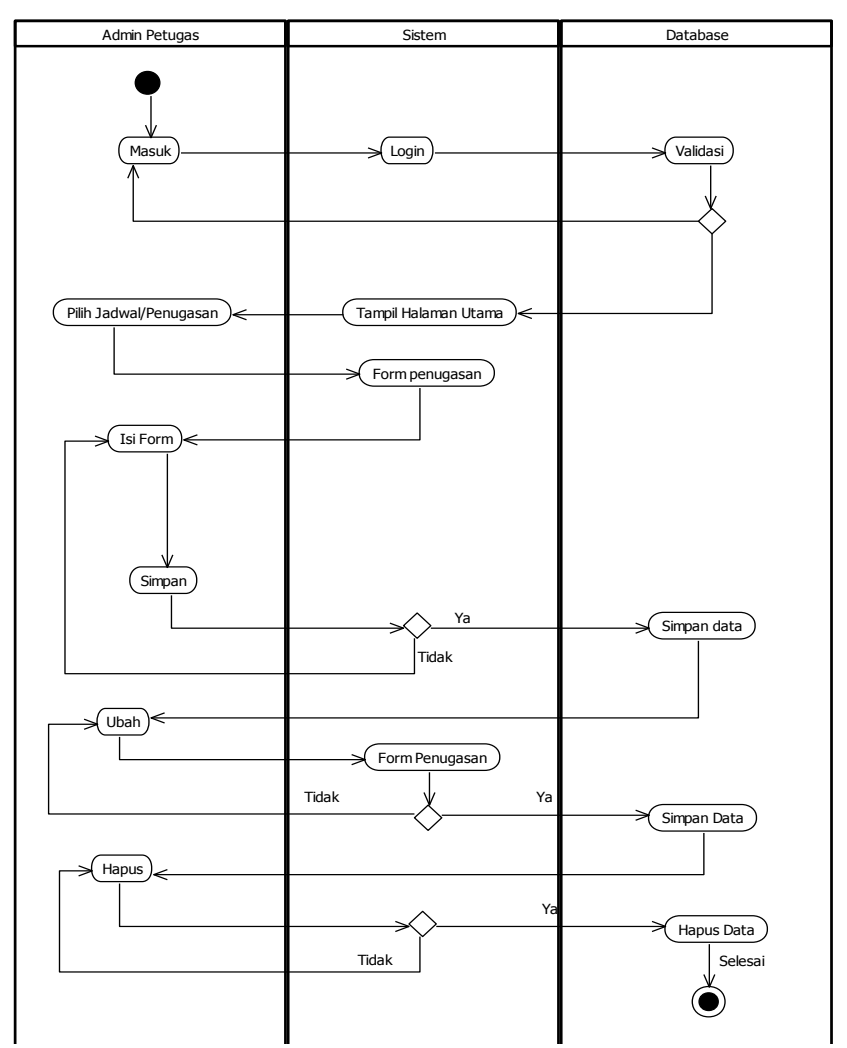

Gambar 7. Activity diagram penjadwalan petugas

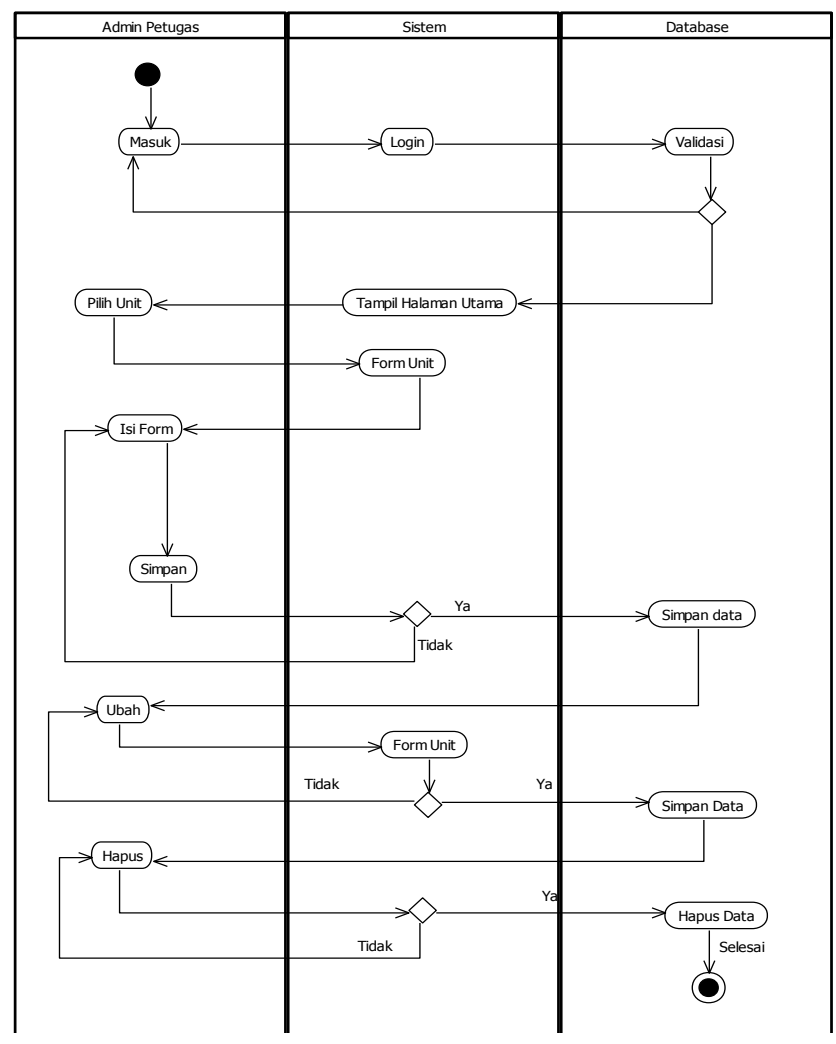

Gambar 8. Activity diagram unit lokasi
3. Activity Diagram Admin Keuangan

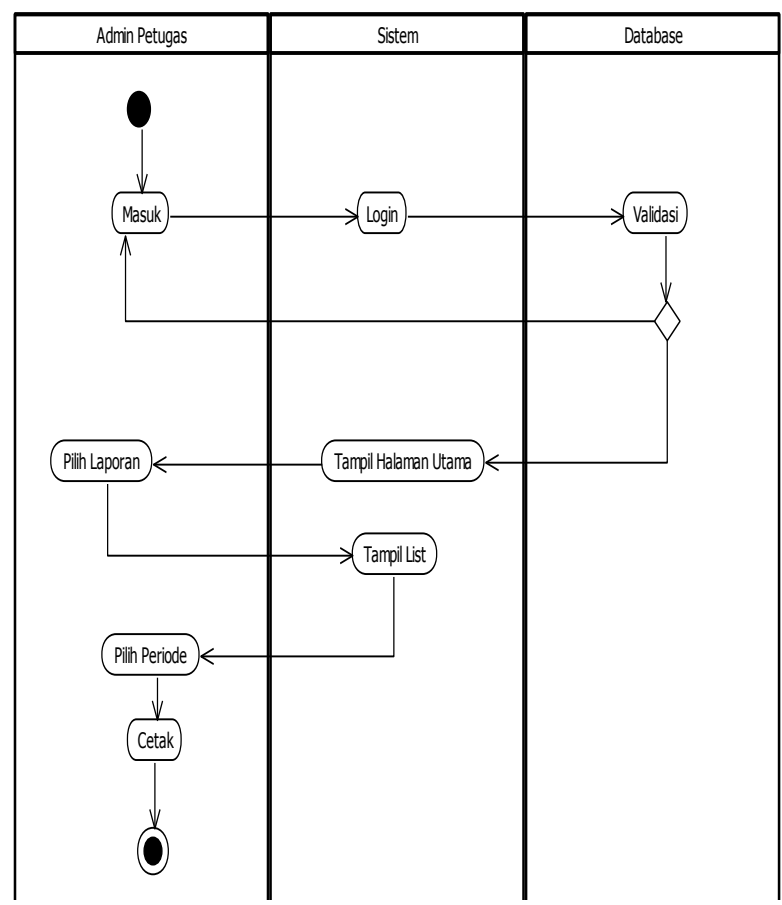

Gambar 9. Activity diagram laporan keuangan

\section{Perancangan Database}

Perancangan database yang dimaksud pada class diagram disini adalah hubungan antara Tabel-Tabel yang yang terkait dalam menunjang sistem monitoring. Berikut pada gambar 10 adalah Gambar class diagram sistem monitoring:

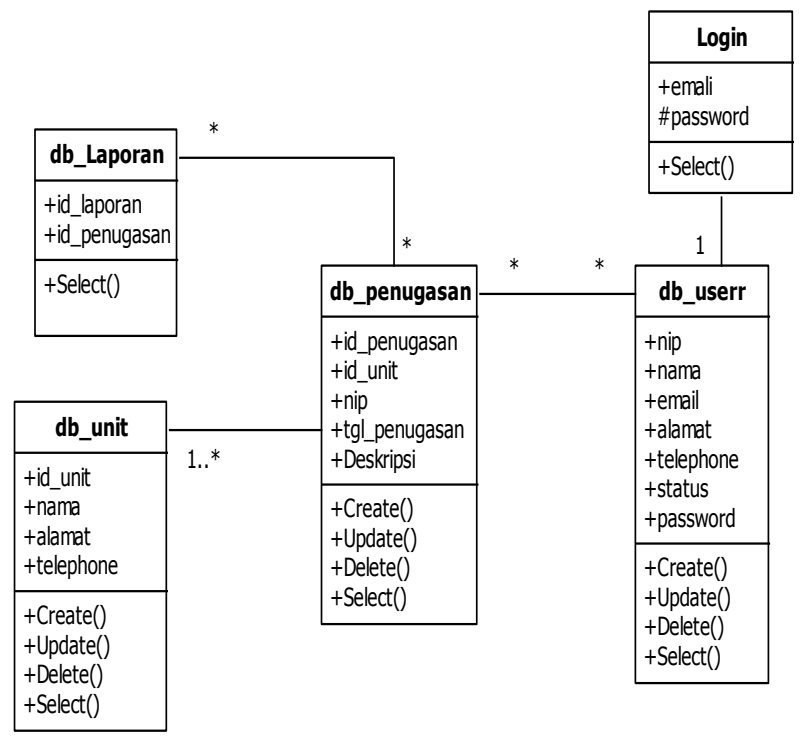

Gambar 10. Class diagram perancangan database monitoring

\section{Pengkodean Sistem}

Hasil Perancangan sistem yang sudah dibuat kemudian di implementasikan kedalam bentuk kode program atau bahasa pemrograman. Berikut pada Gambar 11, Gambar 12, Gambar 13, Gambar 14 dan Gambar 15 adalah Gambar hasil pengkodean sistem monitoring: 

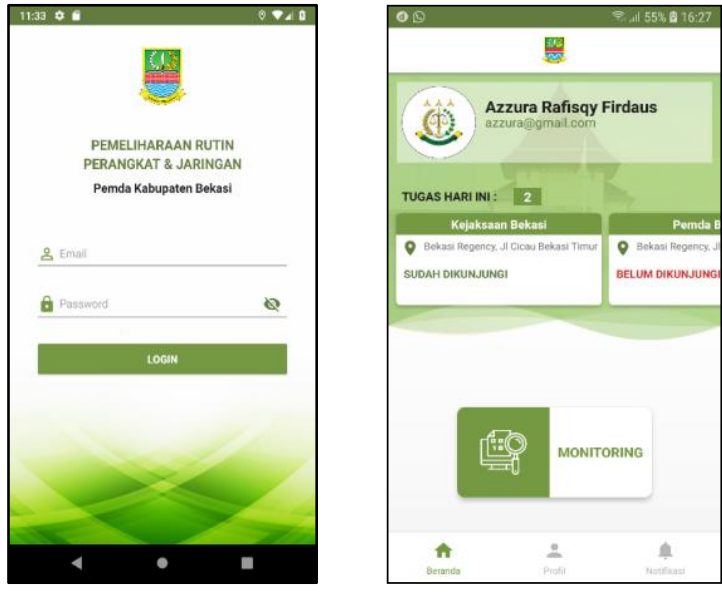

1. Interface Sistem Monitoring Petugas Lapangan

Gambar 11. Login petugas lapangan dan halaman utama sistem monitoring
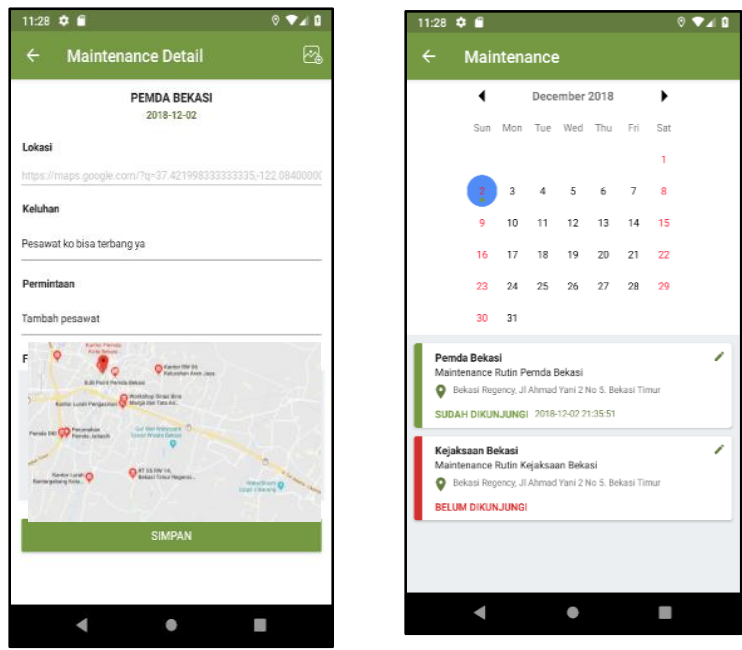

Gambar 12. Jadwal petugas lapangan dan form monitoring

2. Interface Sistem Monitoring Admin Petugas

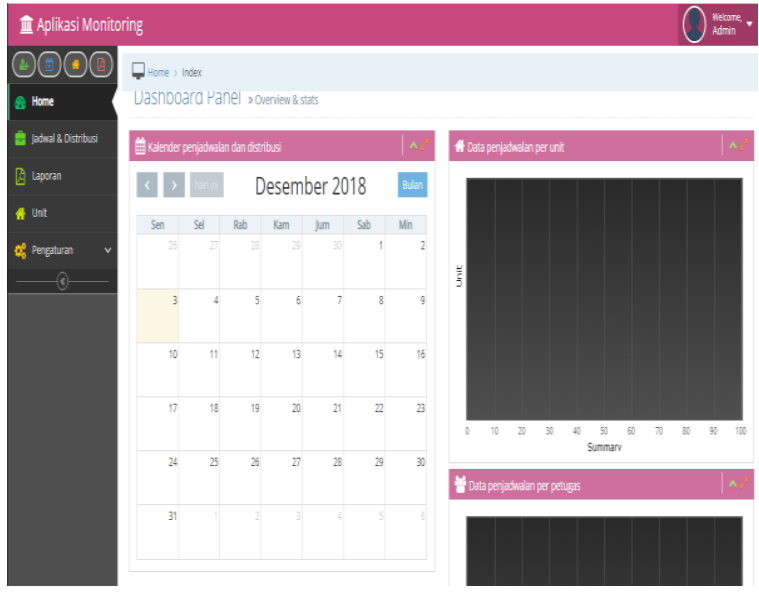

Gambar 13. Penugasan pegawai lapangan

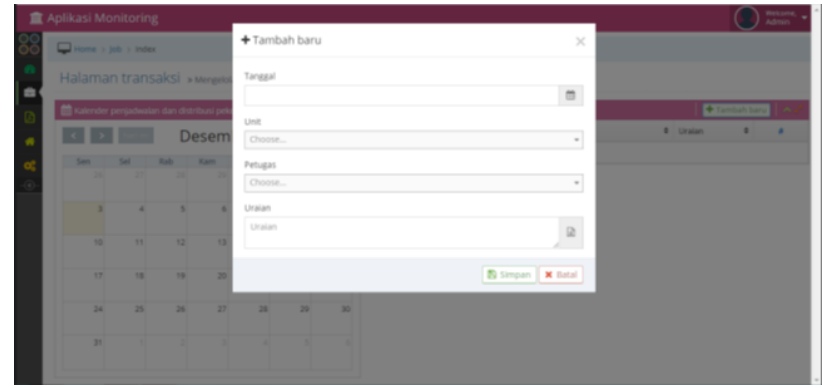

Gambar 14. Form tambah penugasan pegawai lapangan

3. Interface Sistem Monitoring Admin Keuangan

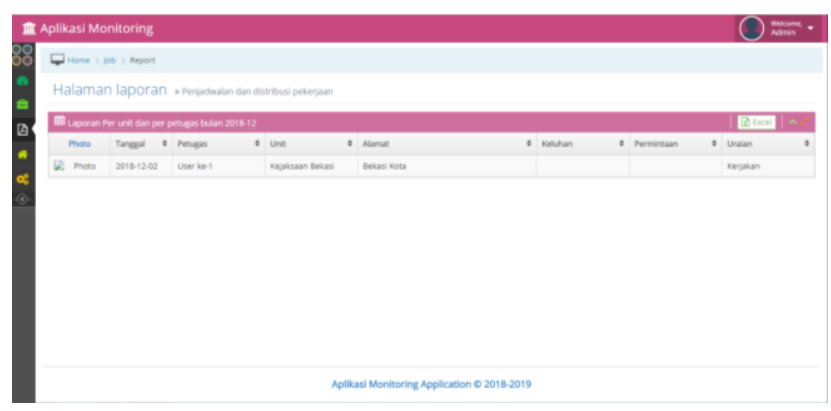

Gambar 15. Laporan hasil penugasan pegawai lapangan

\section{E. Pengujian Sistem}

Pengujian sistem dengan metode alpha testing dilakukan oleh peneliti dimaksudkan untuk menilai kinerja dari software/sistem monitoring baik dari sisi petugas lapangan, admin petugas lapaangan dan admin keuangan. Penilayan dilakukan setelah masing-masing petugas mengisi form kuesioner. Persamaan (1) digunakan untuk menghitung hasil perhitungan Alpha Testing:

$$
\text { Hasil }=\frac{k}{j} x 100
$$

Keterangan :

1. $\mathrm{k}=$ Total masing-masing jawaban dari Tabel kemudahan sistem ditambah Tabel keakuratan sistem

2. $\mathrm{j}=$ Total keseluruhan jawaban dari Tabel kemudahan sistem ditambah Tabel keakuratan

Hasil dari pengujian alpha testing dapat dilihat pada Tabel 1 dan Gambar 16.

Tabel 1. Hasil perhitungan Alpha Testing

\begin{tabular}{|c|l|c|c|c|c|c|}
\hline \multirow{2}{*}{ No } & \multirow{2}{*}{$\begin{array}{l}\text { Kemudahan } \\
\text { dan } \\
\text { Interface } \\
\text { Sistem }\end{array}$} & \multicolumn{5}{|c|}{ Hasil } \\
\cline { 2 - 7 } & $\mathbf{( \% )}$ & $\begin{array}{c}\text { S } \\
(\%)\end{array}$ & $\begin{array}{c}\text { KS } \\
(\%)\end{array}$ & $\begin{array}{c}\text { TS } \\
(\%)\end{array}$ & $\begin{array}{c}\text { STS } \\
(\%)\end{array}$ \\
\hline 1 & $\begin{array}{c}\text { Petugas } \\
\text { Lapangan }\end{array}$ & 79.62 & 9.26 & 9.02 & 2.08 & 0 \\
\hline 2 & $\begin{array}{c}\text { Admin } \\
\text { Petugas dan } \\
\text { Keuangan }\end{array}$ & 90.44 & 1.55 & 0 & 0 & 0 \\
\hline
\end{tabular}




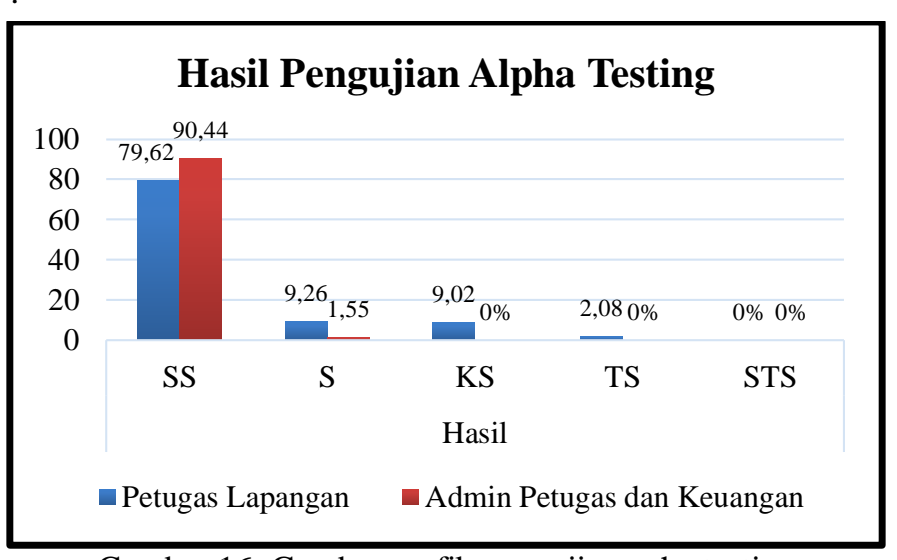

Gambar 16. Gambar grafik pengujian apha testing

\section{KESIMPULAN DAN SARAN}

Hasil pengujian data petugas lapangan menunjukan bahwa $79,62 \%$ menyatakan sangat setuju, 9,26\% menyatakan setuju dan sisanya menyatakan tidak setuju. Sebagian banyak petugas setuju dengan sistem yang telah dibuat dan hanya sedikit petugas yang tidak setuju dengan aplikasi tersebut. Dari data admin petugas dan keuangan menunjukan bahwa 90, $44 \%$ menyatakan sangat setuju, 1,55\% menyatakan setuju dan sisanya menyatakan tidak setuju.

Dari hasil pengujian, metode alpha testing, dapat disimpulkan bahwa sistem monitoring yang telah dibuat mudah dan layak untuk digunakan. Akan tetapi untuk mendapatkan hasil yang maksimal perlu adanya pengembangan sistem yang lebih lanjut, seperti memperbaiki akurasi maping dan penggunaan map yang open source (Openmaping).

\section{DAFTAR PUSTAKA}

[1] A. Kushwaha and V. Kushwaha, "Location Based Services using Android Mobile Operating System," Int. J. Artif. Intell. Knowl. Discov., vol. 1, no. 1, pp. 14-20, 2011.

[2] A. Hendini, "Pemodelan UML sistem informasi Monitoring Penjualan dan stok barang," Pemodelan Uml Sist. Inf. Monit. Penjualan Dan Stok Barang (Studi Kasus Distro Zhezha Pontianak), vol. IV, no. 2, pp. 107-116, 2016.

[3] S. Lorena, B. Ginting, Y. Ahmad, and G. Saputra, "Pemanfaatan Teknologi LBS dan Penerapan Teknologi Augmented Reality Pada Pembangunan Aplikasi Denah Petunjuk Ruangan ( Studi Kasus: Unikom Bandung ) The Use of LBS Technology and The Application of Augmented Reality Technology in The Development of Room ."

[4] D. . Michael and D. Gustina, "Rancang Bangun Prototype Monitoring Kapasitas Air Pada Kolam Ikan Secara Otomatis Dengan Menggunakan Mikrokontroller Arduino," J. IKRA-ITH Inform. Vol 3 No 2 Juli 2019 ISSN 2580-4316, vol. 3, no. 2, pp. 5966, 2018.

[5] D. P. Buwana, S. Setiawidayat, and M. Mukhsin, "Sistem Pengendalian Lampu Penerangan Jalan
[6] C. Framework, "Teacher Monitoring Application in Umum (PJU) Melalui Jaringan Internet Berbasis Android," JOINTECS (Journal Inf. Technol. Comput. Sci., vol. 3, no. 3, pp. 149-154, 2018.

Teaching Based on CodeIgniter Framework in High Schools," Buana Inf. Tchnology Comput. Sci. (BIT CS) Teach., vol. 1, no. 1, pp. 12-15, 2020.

[7] D. Kurniawan and B. Priyatna, "Pengamanan Data Berbasis Mobile Android Dengan Penggabungan Linear Feedback Shift Register ( Lfsr ) Dan Modifikasi Matriks," J. Telemat. MKOM, vol. 10, no. 1, pp. 42-46, 2018.

[8] S. Samsinar and U. B. Luhur, "BARANG DENGAN METODOLOGI BERORIENTASI OBYEK STUDI KASUS : PADA PT . MOIKO TASINDO," no. March, 2018.

[9] A. Solehudin, N. Heryana, and Y. Cahyana, "Designing and Building Client-Server Based Student Admission Applications," Buana Inf. Tchnology Comput. Sci. (BIT CS), vol. 1, no. 1, pp. 16-18, 2020.

[10] L. Apriliana, U. D. Darusalam, and N. D. Nathasia, "Clustering Server Pada Cloud Computing Berbasis Proxmox VE Menggunakan Metode High Availability," JOINTECS (Journal Inf. Technol. Comput. Sci., vol. 3, no. 1, 2018.

[11] S. Kosasi and I. D. A. E. Yuliani, "Simetris: jurnal teknik mesin, elektro dan ilmu komputer.," Simetris J. Tek. Mesin, Elektro dan Ilmu Komput., vol. 6, no. 1, pp. 27-36, 2015.

[12] T. Wahyuningrum and D. Januarita, "Perancangan Web e-Commerce dengan Metode Rapid Application Development ( RAD ) untuk Produk Unggulan Desa," vol. 2014, no. November, pp. 81-88, 2014.

[13] S. Antonio Gusmao, Sholeh Hadi Pramono, "Sistem Informasi Geografis Pariwisata Berbasis Web Dan Pencarian Jalur Terpendek Dengan Algoritma Dijkstra," J. Electr. Electron. Commun. Control. Informatics, Syst., vol. 7, no. 2, pp. 125-130, 2013.

[14] F. T. Industri, J. T. Informatika, and U. K. Petra, "Perencanaan Rute Perjalanan Di Jawa Timur Dengan Dukungan Gis Menggunakan Metode Dijkstra S," J. Inform., vol. 3, no. 2, pp. 63-63, 2002.

[15] A. A. Salam, "Sistem Informasi Geografis Pemetaan Aset Daerah Menggunakan Algoritma Djikstra Di BKD Kota Cirebon,” vol. 1, no. 1, pp. 1-11, 2019. 
